\title{
Analysis of Relation Between Financial Performance and the Use of Lean Six Sigma by the Top Fortune Companies Worldwide as Published by Forbes Magazine
}

\author{
Ismail Idrissi, Ilham Aftais, Abdelhalem. Mesfioui, Bouchra Benazzouz \\ Laboratoire de Génétique, Neuroendocrinologie et Biotechnologie, Faculté des Sciences, Université Ibn Tofail, \\ Kénitra, Maroc
}

\begin{abstract}
-
Lean Six Sigma represents a management approach for driving innovating processes inside a company in order to achieve superior results. It involves a practical analysis based on facts, aiming the innovation and growth, not only the efficiency of processes. It is a long term process of gradual and continuous improvement. The application of Lean Six Sigma in companies led to attaining superior financial performance by addressing new needs, by differentiating the products and services or by adjusting the business lines to new processes. Quality is more than making things without errors. It is about making a product or service meet the individual perception of a customer about the quality or value. Therefore, in what regards Lean Six Sigma, the concern is not only to "do the things right" but also to "do the right things right". We focus on the impact of implementing the Lean Six Sigma approach on Forbes Top 25 companies, seeking for the correlation between the implementation of Lean six sigma and the performance of top 25 Forbes companies. 22 of the 25 top fortune companies communicate that they use Lean six sigma to improve performance.
\end{abstract}

Keywords: Lean Six Sigma, innovation, strategy, quality, gradual and continuous process, top 25 fortune companies

Date of Submission: 23 December 2016

$\longrightarrow$ บ

Date of Accepted: 05 January 2017

\section{INTRODUCTION}

Competition has become more and more fierce, customers are demanding higher quality at lower prices and profit margins seem to be falling especially in times of crisis. An efficient and effective strategy to become more competitive is to adopt Lean Six Sigma. Quality is more than making things without errors. It is about making a product or service meet the individual perception of a customer about the quality or value. Therefore, in what regards Lean Six Sigma, the concern is not only to "do the things right" but also to "do the right things right". In the present study we focus on the use of Lean six sigma by the top fortune companies worldwide as published by Forbes Magazine

\section{KEY ELEMENTS OF LEAN SIX SIGMA}

Six Sigma is both a statistical measure of variation in a process and a strategy of business management, developed by Motorola in 1981, to increase quality, eliminate the root causes of defects and reduce variation and defects within its manufacturing processes. Six Sigma programs aim at improving competitive positioning and increasing the value of the company as perceived by the customer. A Six Sigma process has, as a statistical quality goal, the achievement of a quality level equal to maximum 3.4 defects per million opportunities for defects, which is $+/$ - six standard deviations from the mean. As of 2006 Motorola reported over US\$17 billion in savings (About Motorola University, 2006) from Six Sigma. Nowadays it is used for a variety of processes and fields of activity. It also focuses on reducing variability within a formalized project management structure. This implies the stability and the predictability of results. In fact, the management structure for executing and managing projects is a real strength of the Six Sigma approach. When executed well, Six Sigma can help an organization achieve very significant improvements in quality, reduction of defects, and ultimately lower cost (Swartwood, 2003).

The principles of Six Sigma (SS):

- Focus on customer needs;

- Continuous effort to reduce process variation using statistical analysis; - Improvement and control of processes;

- Teamwork and involvement from all levels of organization, especially from top-level management. 
A widely accepted definition of lean manufacturing is the "systematic approach to identify and eliminate waste (non value-adding activities) through continuous improvement by flowing the product at the pull of the customer in the pursuit of perfection" (Brue \& Howes, 2006). It focuses on reducing the business cycle time so as to become more responsive to customer demand, while using less resources and improving products and processes. These materialize in lower costs, increased productivity and highly profitable and flexible production capability, overall, an increased operational efficiency. In 1990 the lean concept becomes popular in American factories after the study by the Massachusetts Institute of Technology of the shift from mass production to a disciplined, process-focused production. The term "lean" refers to the cut off the "fat" (waste) - anything bringing no added-value for a customer or something he is unwilling to pay for (Brue \& Howes, 2006). The aim of Lean is to create simplified, efficient value-adding processes while sharing information. Successful Lean initiatives yield lower inventory cost, higher productivity and flexibility, and faster response time to the customer (Subramaniam, 2007).

Table 1 indicates a few types of waste where Lean can be applied.

Source: adapted from Brue \& Howes (2006)

\begin{tabular}{|c|c|c|}
\hline Type of waste & Content & Lean Target \\
\hline Correction & $\begin{array}{l}\text { Reworking and } \\
\text { repairing }\end{array}$ & $\begin{array}{l}\text { - Solves the following: } \\
\text { - Inadequate process control; } \\
\text { - Poor quality; } \\
\text { - Insufficient training; } \\
\text { - Poor product design; } \\
\text { - Unclear customer needs. }\end{array}$ \\
\hline Overproduction & $\begin{array}{l}\text { Producing more than } \\
\text { necessary or earlier } \\
\text { than needed }\end{array}$ & $\begin{array}{l}\text { - Uses process automation; } \\
\text { - Smoothes scheduling. }\end{array}$ \\
\hline $\begin{array}{l}\text { Inventory and work } \\
\text { in process }\end{array}$ & Excess inventory & $\begin{array}{l}\text { - Solves the following: } \\
\text { - Inefficiencies; } \\
\text { - } \quad \text { Product complexity; } \\
\text { - Bad scheduling; } \\
\text { - Unreliable deliveries; } \\
\text { - Poor communications. }\end{array}$ \\
\hline $\begin{array}{l}\text { Unnecessary } \\
\text { process steps }\end{array}$ & $\begin{array}{l}\text { Non-value adding } \\
\text { activities }\end{array}$ & $\begin{array}{l}\text { - Questions every step whether it is } \\
\text { necessary }\end{array}$ \\
\hline Wait & $\begin{array}{l}\text { Being idle between } \\
\text { operations or while a } \\
\text { machine is processing }\end{array}$ & $\begin{array}{l}\text { - Maximizes the use of workers } \\
\text { byanalyzing work load and work } \\
\text { flow, production and maintenance } \\
\text { schedules, sets up times and } \\
\text { procedures }\end{array}$ \\
\hline Transportation & $\begin{array}{l}\text { Causing damage and } \\
\text { waste of time by } \\
\text { moving } \\
\text { products/processes }\end{array}$ & $\begin{array}{l}\text { - Identifies the process flow, the } \\
\text { inefficient site layout and lead-times }\end{array}$ \\
\hline Motion & $\begin{array}{l}\text { Unnecessary, } \\
\text { awkward, dangerous } \\
\text { moving of workers or } \\
\text { inappropriate } \\
\text { relocation of the } \\
\text { organization }\end{array}$ & $\begin{array}{l}\text { - Focus on: } \\
\text { - Efficiency of motions; } \\
\text { - Most convenient workplace. }\end{array}$ \\
\hline $\begin{array}{l}\text { Underutilizing } \\
\text { people }\end{array}$ & $\begin{array}{l}\text { Not using the full } \\
\text { potential of } \\
\text { employees }\end{array}$ & $\begin{array}{l}\text { - Emphasizes on: } \\
\text { - Better hiring practices; } \\
\text { - Better training; } \\
\text { - Higher financial benefits; } \\
\text { - Improved organizational culture. }\end{array}$ \\
\hline
\end{tabular}

Six Sigma, on the other hand, targets the following types of waste materialized in costs:

- rework;

- scrap;

- excessive cycle times and delays;

- unsatisfied customers with the goods and/or services provided;

- cost of opportunities lost due to lack of resources to take advantage of;

- poor quality.

The integration of the Lean Principles into Six Sigma (or reversely) makes it possible to achieve effective improvements. This methodology was named Lean Six Sigma.

SS uses the methodology of DMAIC (Do, Measure, Analyze, Improve and Control) and DMADV (Define, Measure, Analyze, Design and Verify) which bring out measurable and repeatable results. Lean uses "Kaizen events" - intensive, typically week-long improvement sessions - to quickly identify improvement opportunities. The statistical tools used in Lean, in Six Sigma are described in the following table: 
Table 2. Statistical tools of LSS

Source: adapted from Subramaniam (2007)

\begin{tabular}{|l|l|}
\hline \multicolumn{1}{|c|}{ Six Sigma } & \multicolumn{1}{c|}{ Lean } \\
\hline $\begin{array}{l}\text { Statistical methods: ANOVA, regression, sigma } \\
\text { calculation, process capability indices }\end{array}$ & Lean transformation \\
\hline Design of Experiments & Demand flow management \\
\hline \multicolumn{1}{|c|}{ Both Six Sigma and Lean } & Cycle time Reduction \\
\hline Control charts & Setup reduction \\
\hline Poka-Yoke & Waste identification \\
\hline Procedure documentation & Product segmentation \\
\hline Visual management & Kaizen Biltz \\
\hline Problem solving method & Value Tree \\
\hline Quality tools and techniques & Value Stream \\
\hline
\end{tabular}

In order to determine how much variation is acceptable to for customers for example, there are set two limits: lower specification limit (LSL or lower tolerance limit - LTL) and an upper specification limit (USL or upper tolerance limit - UTL). The objective is to ultimately reduce variation in the processes so that $99,99966 \%$ of the outputs will fall between the LSL and USL (Brue \& Howes, 2006).

Additionally, there are two control limits designing the desirable thresholds for the process: the lower and the upper control limit (LCL and UCL). If the control limits are within the specification limits, the process is considered able to meet the specifications.

Process capability represents a statistical measure for a specific characteristic within a stable process. It measures the ability of a process to produce outputs that meet the specification.

As processes shift over time, there were introduced the measure of capability on a short and on a long term. And although 3,4 defects per million opportunities corresponds to 4,5 sigma distribution between the mean and the closest specification limit, the target is raised to 6 Sigma to compensate for shifts over time.

The most common indices used to measure process capability are: $\mathrm{Cp}$ (process capability) and Cpk (process performance). $\mathrm{Cp}$ is a measure of the width of a distribution of outputs of the process and Cpk also indicates how close the average value to the target value is.

A better metric is the rolled throughput yield, which is the probability that a single unit can pass through all the steps in a process free of defects.

The cost of poor quality, another metric for SS, is the cost of doing things wrong, the total of all the costs of all defects in the processes.

Both Lean and Six Sigma are built around the view that businesses are composed of processes that start with customer needs and should end with satisfied customers currently or after using the product or service.

However, the goal of Lean Six Sigma is growth, not just cost-cutting. It aims both effectiveness and efficiency. This way, a Lean Six Sigma approach drives organizations not just to do things better, but to do better things.

\section{COMPANY REQUIREMENTS FOR LEAN SIX SIGMA IMPLEMENTATION}

The first step to implement LSS is to identify the critical elements of a process. Then team analyzes its capability and tries to stabilize it by reducing or eliminating variations. The basic transfer function is applied, which depends on the vital few factors. The SS methodology uses the DMAIC (Define, Measure, Analyze, Improve, Control) or DMADV (Define, Measure, Analyze, Design and Verify) model. DMAIC strategy consists of (Brue \& Howes, 2006):

- Define - the projects, the goals, the deliverables for the customers; describe and quantify the defects and the expected improvement;

- Measure - identify the baselines, the current performance of the process; methods used: process mapping, descriptive statistics and matrices, capability studies, measurement systems;

- Analyze - and determine the source(s) of defects using specific tools; narrow the causal factors to the vital few; potential solutions; methods used: distribution analysis, graphics, multivariate analysis, hypothesis testing, plan project applications;

- Improve - the process to eliminate defects; optimize the vital few and their interrelationships based on the analysis of the previous step; methods used: design of experiments, complete factorial experiments and continue executing and improving the project plan;

- Control - ensure the performance of the process and lock down the gains; statistical methods of control are used. 
An easy integration of LSS initiative into the management approach implies a cultural change at all levels of organization, with a special stress on the top management level. They must commit their time, energy and the resources of the company to promote the initiative. One reason Six Sigma implementation failed in many companies was due to the lack of commitment from management. Furthermore, stakeholders like external partners and suppliers are also advisable to be involved for a better quality of results of continuous and homogenous improvement, as well as for simplifying the processes. Additionally, an organization seeking to implement LSS should be having or hiring multi-skilled employees.

\section{IMPACT OF IMPLEMENTING THE LEAN SIX SIGMA APPROACH ON COMPANIES}

We go on by illustrating some of the financial impact of implementing LSS on companies:

Table 3. Financial benefits after implementation of LSS on companies

Source: adapted from Brue \& Howes (2006)

\begin{tabular}{|c|c|}
\hline Company & Impact of Lean Six Sigma \\
\hline General Electric & $\begin{array}{l}\text { added } \$ 2 \text { billion in } 1999 \text { and } \$ 2,4 \text { billion in } 2000 \text { to the } \\
\text { bottom line }\end{array}$ \\
\hline Motorola & saved $\$ 1,5$ billion in the first ten years of $\mathrm{SS}$ \\
\hline $\begin{array}{l}\text { Honeywell (former } \\
\text { Allied Signal) }\end{array}$ & $\begin{array}{l}\text { - reduced costs by } \% 1,4 \text { billion from } 1992 \text { through } 1996 ; \\
\text { - reduced new product introduction time by } 16 \% \text {. }\end{array}$ \\
\hline DuPont & $\begin{array}{l}\text { - saved } \$ 1,6 \text { billion in four years; } \\
\text { - reduced environmental impact. }\end{array}$ \\
\hline Johnson Controls & $\begin{array}{l}\text { For the Ohio manufacturing plant: } \\
\text { - reduced defects by } 70 \% \text {; } \\
\text { - reduced costs } \$ 800,000 \text { per year. } \\
\text { For the automotive operations in Michigan: } \\
\text { - saved } \$ 943,000 \text { per year through greater engineer } \\
\text { productivity. }\end{array}$ \\
\hline $\begin{array}{l}\text { Mount Carmel Health } \\
\text { System }\end{array}$ & $\begin{array}{l}\text { - financial return of } \$ 2,4 \text { million after the first year of } \\
\text { implementing SS; } \\
\text { - saved } \$ 35,8 \text { million by early } 2004 \text { after investing only } \\
\$ 600,000 \text { in SS training and consulting. }\end{array}$ \\
\hline
\end{tabular}

It is estimated that one could expect a minimum return on investment of three or four times the costs of implementing SS in around one year and a half (Brue \& Howes, 2006).

Since the financial part is decisive in choosing whether to initiate a project, managers and shareholders are interested to know the benefits of implementing LSS to their companies.

LSS applied to the processes of a company can lead not only to lower costs and increased productivity but also to a better customer satisfaction, to a diversified offer and to a better distribution in terms of geographical coverage and number of shops.

One way to quantify the impact of implementing LSS to a business is computing several indicators as follows*:

1. customer satisfaction index (ISIXSIGMA, 2010);

2. customer penetration rate (ISIXSIGMA, 2010);

3. customer winning rate (ISIXSIGMA, 2010);

4. supply chain flexibility;

5. reduction of lead-time;

6. quality across the board;

7. total cost for each process.

* Indicators from 1 to 6 refer to metrics for SS and indicator 7 represents a performance metric for Lean

The time period over which the results of implementing LSS can be seen, ranges from one year up to three years.

Nonfinancial or indirect advantages include (Brue \& Howes, 2006):

- $\quad$ benefits for the customers (better, cheaper and faster services and products);

- benefits for the employees (increased motivation, active involvement, participation in decision making process, improved skills);

- improved quality and a thorough change in the culture of an organization.

\section{STRATEGIES TO OBTAIN THE MAXIMUM PRACTICAL OUTCOME}

How can a company generate new improved solutions for the problems it encounters? The basic ways used in LSS are: the community of best practices (where people exchange ideas), ideas from other projects, brainstorming, setting performance targets, benchmark ideas, and discoveries made during analysis, project goals and root causes.

There are basically two causes of variation: 
1) Common causes - leading to random variation caused by factors linked to the process; this is the result of several factors acting independently and randomly causing a small impact;

2) Special causes - leading to nonrandom variation caused by external factors; the causes are unpredictable and the outcomes are unexpected.

By distinguishing which type is the variation cause, a specific strategy to be used. Special variation causes must be eliminated first, this implies immediate action. Common causes of variation are to be reduced on a long term. In order to obtain the maximum outcome, a company should extend the LSS principles across its departments and processes, using integrated business support software. These applications provide an efficient knowledge and information management, especially when the managers deal with a multitude of projects in the same time. To point just a few examples:

- $\quad$ time management of the projects;

- what are the gains of deploying LSS of each project;

- monitoring and displaying a summary of the ongoing processes; this can also provide a remote control of the outsourcing projects;

- within a project, when making a change to one application (either by a manager either by a client), all the other applications are updated and all responsible of the project are notified;

- $\quad$ point out which are the non-value-adding activities;

- change and improvement of the support software according to changes in the customer expectations.

One example of implementing LSS is within a university in order to facilitate the admission process, to solve the problems encountered by students and also for a better communication between students and the management of the university.

This implies building a services center for students centralizing, in the same area, the main offices needed to create the interface between students and management of the university. The employees need to be highly trained so they can respond efficiently and effectively to the problems of students and provide all the information needed.

Another example of implementing Lean strategy was used by Henry Ford for limiting the colors of the cars produced to only one - black. Thus, he ensured a greater production and saving costs because the black color was the cheapest color to purchase.

Analysis of relation between financial performance and the use of Lean six sigma by the top fortune companies worldwide as published by Forbes Magazine

The analysis of relation between financial performance and the use of Lean six sigma by the top fortune companies worldwide as published by Forbes Magazine is summarized in the following table:

Table 4 The analysis of relation between financial performance and the use of Lean six sigma by the top fortune companies worldwide as published by Forbes Magazine

\begin{tabular}{|c|c|c|c|c|c|c|c|c|}
\hline 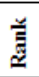 & Company & Country & Activity & Sales & Earnings & $\begin{array}{l}\text { Uses Lean } \\
\text { Six } \\
\text { Sigma? }\end{array}$ & Source & $\begin{array}{l}\text { Consultation } \\
\text { date }\end{array}$ \\
\hline 1 & ICBC & China & Banque et finances & $\$ 134.8 \mathrm{~B}$ & $\$ 37.8 \mathrm{~B}$ & Oui & Annual report & $21 / 04 / 2013$ \\
\hline 2 & China Construction Bank & China & Banque et finances & $\$ 113.1 \mathrm{~B}$ & $\$ 30.6 \mathrm{~B}$ & Oui & Annual report & $21 / 04 / 2013$ \\
\hline 3 & JPMorgan Chase & United States & Banque et finances & $\$ 108.2 \mathrm{~B}$ & $\$ 21.3 \mathrm{~B}$ & Oui & isix sigma magazine & $21 / 04 / 2013$ \\
\hline 4 & General Electric & United States & $\begin{array}{l}\text { Conglomérats } \\
\text { économiques }\end{array}$ & $\$ 147.4 \mathrm{~B}$ & $\$ 13.6 \mathrm{~B}$ & Oui & Ge.com & $21 / 04 / 2013$ \\
\hline 5 & Exxon Mobil & United States & Telecom & $\$ 420.7 \mathrm{~B}$ & $\$ 44.9 \mathrm{~B}$ & Oui & Dom.com & $21 / 04 / 2013$ \\
\hline 6 & HSBC Holdings & $\begin{array}{l}\text { United } \\
\text { Kingdom }\end{array}$ & Banque et finances & $\$ 104.9 \mathrm{~B}$ & $\$ 14.3 \mathrm{~B}$ & Oui & isix sigma magazine & $21 / 04 / 2013$ \\
\hline 7 & Royal Dutch Shell & Netherlands & Industrie pétrolière & $\$ 467.2 \mathrm{~B}$ & $\$ 26.6 \mathrm{~B}$ & Oui & Scell.com & $21 / 04 / 2013$ \\
\hline 8 & wril & China & Banque et finances & $\$ 103 \mathrm{~B}$ & $\$ 23 \mathrm{~B}$ & $?$ & Informationnot commuricated & $21 / 04 / 2013$ \\
\hline 9 & Berkshire Hathaway & United States & $\begin{array}{ll}\text { Services } & \text { à } \\
\text { l'investissement }\end{array}$ & $\$ 162.5 \mathrm{~B}$ & $\$ 14.8 \mathrm{~B}$ & Oui & isix sigma magazine & $21 / 04 / 2013$ \\
\hline 10 & PetroChina & China & Industrie pétrolière & $\$ 308.9 \mathrm{~B}$ & $\$ 18.3 \mathrm{~B}$ & $?$ & Informationnot commuricated & $21 / 04 / 2013$ \\
\hline 11 & Bank of China & China & Banque et finances & $\$ 98.1 \mathrm{~B}$ & $\$ 22.1 \mathrm{~B}$ & Oui & $\begin{array}{ll}\text { INTERNATIONAL } & \text { SIX } \\
\text { SIGMA COUNCIL } & \\
\end{array}$ & $21 / 04 / 2013$ \\
\hline 12 & Wells Fargo & United States & Banque et finances & $\$ 91.2 \mathrm{~B}$ & $\$ 18.9 \mathrm{~B}$ & Oui & Rapport annuel & $21 / 04 / 2013$ \\
\hline 13 & Chevron & United States & Industrie pétrolière & $\$ 222.6 \mathrm{~B}$ & $\$ 26.2 \mathrm{~B}$ & Oui & $\begin{array}{l}\text { Intemational Society of Six } \\
\text { Sigma Professionals }\end{array}$ & $21 / 04 / 2013$ \\
\hline 14 & Volkswagen Group & Germany & Industrie automobile & \$254 B & $\$ 28.6 \mathrm{~B}$ & Oui & isix sigma magazine & $21 / 04 / 2013$ \\
\hline 15 & Wal-Mart Stores & United States & Grande distribution & $\$ 469.2 \mathrm{~B}$ & \$17 B & Oui & $\begin{array}{lll}\text { Engineering Lean \& Six } \\
\text { Sigma Conference 2012 }\end{array}$ & $25 / 04 / 2013$ \\
\hline 15 & Apple & United States & Matériel informatique & $\$ 164.7 \mathrm{~B}$ & $\$ 41.7 \mathrm{~B}$ & Oui & Xraydelta & $25 / 04 / 2013$ \\
\hline 17 & Gazprom & Russia & Industrie pétrolière & $\$ 144$ B & $\$ 40.6 \mathrm{~B}$ & Oui & $\begin{array}{l}\text { Profil publique de Mikhail } \\
\text { Fedorov sur Linkedin }\end{array}$ & $25 / 04 / 2013$ \\
\hline 18 & BP & $\begin{array}{l}\text { United } \\
\text { Kingdom }\end{array}$ & Industrie pétrolière & $\$ 370.9 \mathrm{~B}$ & $\$ 11.6 \mathrm{~B}$ & Oui & Annual report & $25 / 04 / 2013$ \\
\hline 19 & Citigroup & United States & Banque et finances & $\$ 90.7 \mathrm{~B}$ & $\$ 7.5 \mathrm{~B}$ & Oui & Quality Digest & $26 / 04 / 13$ \\
\hline 20 & Samsung Electronics & South Korea & Matériel informatique & $\$ 187.8 \mathrm{~B}$ & $\$ 21.7 \mathrm{~B}$ & Oui & ASQ & $26 / 04 / 13$ \\
\hline 21 & Petrobras & Brazil & Industrie pétrolière & $\$ 144.1 \mathrm{~B}$ & $\$ 11 \mathrm{~B}$ & Oui & $\begin{array}{l}\text { Rapport annuel de Petrobras } \\
2008\end{array}$ & $26 / 04 / 13$ \\
\hline 22 & BNP Paribas & France & Banque et finances & $\$ 126.2 \mathrm{~B}$ & $\$ 8.6 \mathrm{~B}$ & Oui & Site officiel de BNP Paribas & $26 / 04 / 13$ \\
\hline 23 & Total & France & Industrie pétrolière & $\$ 240.5 \mathrm{~B}$ & \$14.1 B & $?$ & Informationnot conmumicated & \\
\hline 24 & AT\&T & United States & Télécom & $\$ 127.4 \mathrm{~B}$ & $\$ 7.3 \mathrm{~B}$ & Oui & Annual report & \\
\hline 25 & Allianz & Germany & Assurance & $\$ 140.3 \mathrm{~B}$ & $\$ 6.8 \mathrm{~B}$ & Oui & Annual report & \\
\hline
\end{tabular}


According to information communicated by companies throw their annual reports, 22 companies of the 25 studied publish in the annual reports that they use Lean six sigma to improve their performance, so a percentage of $88 \%$ of the studied companies are using Lean six sigma,

This allow us to say that there is a big correlation between the use of Lean six sigma and the performance of companies.

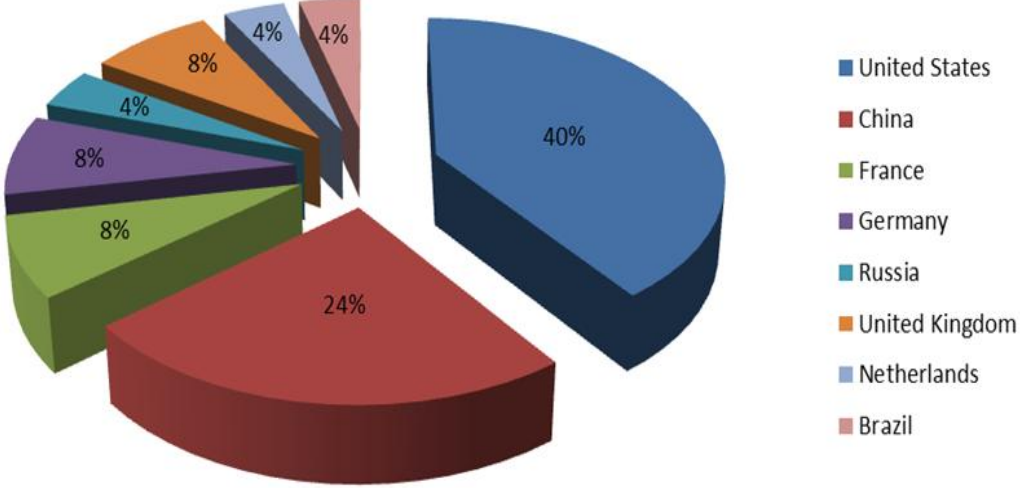

Figure 1: Distribution of top 25 fortune companies by country

\section{CONCLUSIONS}

Six Sigma aims at systematically decrease process variation so as to approach a quality level of near zero defects and increased stability. The standard deviation is to be reduced so that it can fit within the specification limits. At that level of process capability, a shift of 1,5 sigma from the centre materializes in a defect rate of 3,4 defect per million opportunities.

Lean seeks improving the process flow by eliminating waste within the process and in the labour use. Lean is a holistic management approach, targeting the entire process flow. It identifies the inefficiencies to reduce and finally eliminate them, thus improving all the processes that create value added chain for the customers.

LSS is not a statistical program, it uses statistical tools for analyzing and interpreting data.

The implementation of LSS brings along the financial advantages, benefits for the customers, for the employees as well as quality improvement. LSS is not only identifying the wastes inside the company, it is also eliminating the sources of waste. It is a long term, systematic improvement of processes - better, faster and at lower cost, applying to every activity which deals with cost, quality and deadlines.

Companies can adapt quality management approaches depending on the type of economy they are operating in. For a slow growing economy it is better to apply Kaizen whereas for a fast growing one, LSS is better suited. Similarly, LSS has been used more likely in big companies dealing with complicated processes as opposed to smaller companies confronting with simpler processes that cannot support the cost of implementing LSS.

While LSS is a top down approach, Kaizen is the opposite, bottom up.

A series of advantages and disadvantages can be drawn from choosing LSS over Kaizen and reverse. Applying a combination of the two is, in our opinion, to a much greater effect. Also, SS and the knowledge management are compatibles and symbiotic.

Nevertheless, we consider the application of LSS should be efficient so that it does not place a burden too big over companies. Also, the application of LSS should focus more on the results rather than on implementing and the tools should be chosen according to the needs, goals and structure of organization. Furthermore, the methodology of LSS should be used only if necessary, if the solution of the problem is not known in order to avoid waste.

\section{REFERENCES}

[1]. About Motorola University. (2006, January 28). Retrieved from http://web.archive.org/ web/20051222081924/http://www.motorola.com/content/0,,3071-5801,00.html

[2]. Brue, G. \& Howes, R. (2006). Six Sigma, McGraw-Hill, England

[3]. Chakravorty,SatyaS.(2009).Six Sigma programs. An implementation model,International Journalof Production Economics,119,1-16

[4]. ISIXSIGMA, Retrieved 5 October 2010 from http://www.isixsigma.com

[5]. Nist, Sematech (2010). Engineering Statistics Handbook, e-Handbook of Statistical Methods, What is Process Capability?. NIST/Sematech Engineering Statistics Handbook, National Institute of Standards and Technology

[6]. ONESIXSIGMA, Retrieved 5 October 2010 from http://www.onesixsigma.com

[7]. Subramaniam, A. (2007). Integrating Lean Six Sigma, Projects to your strategy - How to integrate LSS - People, Systems, Methods, Roadmaps, Tools \& Techniques, Retrieved from http://www.slideshare.net/anandsubramaniam/lean-six-sigma-projectsstrategy-linkage

[8]. Swartwood, D. (2003). Using Lean, Six Sigma, and Score To Improve Competitiveness, Pragmatek Consulting Group, Retrieved from http://www.bptrends.com/ publicationfiles/1003\%20ART\%20Lean\%20Six\%20Sigma\%20SCOR\%20-\%20Swartwood.pdf

[9]. Truscott, W. (2003). Six Sigma: Continual Improvement for Business. Butterworth Heinemann, England 